\title{
Encouraging and Inhibiting Factors in the Tradition of Commemoration of the Birthday of the Prophet Muhammad SAW Community in Pidie District, Aceh Province of Indonesia
}

\author{
Salman Ishak, Bambang Satriya, Praptining Sukowati \\ University of Merdeka Malang \\ Indonesia
}

\begin{abstract}
The Aceh region is a province where the majority of the people are Muslim. Islam entered and developed in Aceh through preaching by Arab merchants. Islam is the majority religion for the people of Aceh, and since the founding of the Samudra Pasai kingdom, the second Islamic kingdom in Aceh has been marked by Islam as political power in Aceh. The variety of Islamic culture develops in society, one of which is the birthday of the Prophet Muhammad SAW. The Maulid Celebration in Kemukiman Bambi, Peukan Baro District, Pidie Regency has a different nuance to maulid celebrations in other regions. The implementation of Maulid starts from preparing meals and meals at people's homes, commonly called Bue Kulah (rice wrapped in leaves), Idang Meulapeuh (multilevel dishes) brought to Meunasah to be eaten together with residents, orphans and guests from other Mukim. Then it was continued with Meudikee Maulud (praying to the Prophet) and Islamic preaching at night. The purpose of this study is to describe the tradition of implementing the Prophet Muhammad's birthday in Pidie District in Aceh Province, to find out what factors encourage and hinder the tradition of commemorating the Prophet Muhammad's birthday in the community in Pidie District, and what symbols and meanings are contained in the commemoration of the Prophet Muhammad's birthday. SAW in the community in Pidie Regency. The research method is qualitative, the research sample is Tgk. Imum Mukim, ulama and adat, Gampong Geuchik and women leaders. Based on the results of the research, it can be explained that the tradition of carrying out the birthday of the Prophet Muhammad in Aceh and the Bambi Settlement has started since Islam developed in Aceh, the process of implementation is through community deliberations in determining the maulid. The implementation of the maulid consists of several stages, namely the preparation of Bue Kulah, Idang Meulapeeh, eating together, Meudikee, and Da'wah Islamiyah. The implementation of the maulid starts in the month from 12 Wednesdayul Awal to the beginning of Jumadil Akhir. The factors that encourage people to carry out the maulid are a form of gratitude, evidence of religious adherence, togetherness and the spirit of mutual cooperation. The occupational factors are economic factors, and differences of opinion in the celebration of the birthday. The symbol in this study is Bue Kulah (rice smoked with banana leaves and a cone shape). Idang Meulapeh is a dish arranged in a tray brought to Meunasah. The yellow ija (cloth color) symbolizes greatness.
\end{abstract}

Keywords: Tradition, Implementation of Mawlid, Mukim, Bue Kulah, Idang Meulapeh.

\section{INTRODUCTION}

Religion is a role model for its adherents, as well as religious communities in Aceh. In Aceh, before Islam entered the area, Hinduism (mysticism) was the religion of the Acehnese people. Hinduism as a way of life for the people of Aceh is reflected in local ritual activities and traditions. Starting from the 7th / 13th century AD, Islam became the majority religion for the people of Aceh, and the establishment of the Samudra Pasai kingdom (Sultan Malikus Shalih w. 1297) as the second Islamic kingdom in Aceh indicated that political power in Aceh had been controlled by the Acehnese Islamic community.

The first kingdom in Aceh was the Peureulak kingdom which was the first Islamic kingdom in Aceh. The kingdomwas founded on the 1st of Muharram $225 \mathrm{H}$, which was followed by the development of the Islamic education institution "Dayah Cot Kala". These educational institutions became the basis for the development of Islamic science in Aceh which then continued to develop into the source of the development of Islam in the archipelago. Islam entered Aceh through Islamic traders from Arabia. Besides trading, they also introduced Islam to the indigenous population, who at that time were predominantly Hindus by means of preaching and marriage. 
According to Al-Attas, the entry of Islam in the archipelago must adhere to the "general theory of the Islamization of the archipelago", the basis of which is the internal characteristics of Islam in the existing Malay-Indonesian world. Al-Attas said that the concepts, the key terms in Malay-Indonesian literature, had nothing to do with India, but had a direct connection with Arabic.

The concept of Islamization of Acehnese society carried out by preachers according to Sayyed Muhammad Naquib Al-Attas in the book Islam and secularism reports that the Islamization of the Sumatra Region (Aceh) was carried out with a persuasive (sufistic) approach. Da'wah is carried out by means of cultural Islamization, namely local culture is maintained, but cultural normative aspects are adjusted based on Islamic teachings. Among the local cultures that have been preserved and remain valid until now in Aceh are the use of rice, rice, grass, flour, boeh crew and others (item-culture) in the "Peusijeuk (Trait complex culture)" activity in which these ingredients also used in the pre-Islamic cultural community in Aceh. When Islam came, the activity of using these materials is Islamicized by applying the philosophy of "tawasshul (culture)" which is one of the traditions (cultural universal) to bring humans closer to Allah SWT. and efforts to get closer to Allah SWT. is an Islamic recommendation (Islamic universal system).

This phenomenon of Islamization causes Islamic law and Acehnese culture to be inseparable, although they can be distinguished. This is what underlies the philosophy or proverb "hukoem ngeun adat lage substances ngeun sifeut", namely culture in its normative aspect is based on Islamic teachings. That is why Aceh culture is known as Islamic culture. This proverb shows how closely the relationship between adat and Islam is. The customs of society can never be separated from the influence of Islam (Syadily) [1].

As mentioned above, the customs of the people are closely related to Islam, so that sometimes it is difficult to distinguish between religious teachings and customs, because beliefs like this have entered the gaps between the two. Likewise with Islamic principles that have become part of adat or have been enforced. This can be seen, for example, in the ceremonies that are held in connection with the commemoration of Islamic holidays. Commemoration of Islamic religious holidays is the main agenda of Muslims in this area. Even though they consist of various ethnic groups, almost all of the people in Aceh Province perform religious holidays in different ways according to their customs. One of the ceremonies to commemorate religious holidays carried out is to commemorate the birthday of the Prophet Muhammmad SAW. The meaning of this ceremony implies that it is based on the ceremony itself, but basically the ceremony takes the form of a celebration or party. Suyono (1985: 423) states that the ceremony is a traditional party which has been arranged according to customary systems or laws that apply in society [2]. The maulid ceremony in the tradition of the Acehnese people is a feast ceremony which has the highest meaning in the traditional life of the Acehnese people.

The activity of the maulid commemoration ceremony in the tradition of the Acehnese people is a feast ceremony which has the highest meaning in the traditional life of the Acehnese people such as the Maulid activity in Pidie Regency. Pidie District is one of the districts in the Aceh region whose people are very strong in implementing Islamic law as Acehnese people in general, as well as in carrying out ceremonies to commemorate the birthday of the Prophet Muhammad SAW. The ceremony is carried out to commemorate the birthday of Prophet Muhammad SAW. in Pidie Regency, especially in Kemukiman Bambi, it was very lively and with a very diverse menu of food dishes.

Tradition or habit is something that has been done for a long time and continues to be part of the life of a community group until now. Traditions are often carried out by a country, culture, time and religion with the same goal. Another definition of tradition is anything that is passed on or transmitted from the past to the present. Tradition or habit, in the simplest sense, is something that has been done for a long time and is part of the life of a group Public, usually from a country, culture, time, or religionthe same one. The very essence of tradition is existenceinformationwhich are passed on from generation to generation both written and oral, because without this, a tradition could become extinct. In addition, tradition can also be interpreted as a common habit in human society, which will automatically influence the actions and reactions in the daily lives of members of that community.

Tradition, from the point of view of material objects, is that it is material objects that show and remind themselves of their special relationship with past lives. For example, temples, ancient ruins, chariots, several other relics, clearly belong to the sense of tradition.

The purpose of the existing tradition in the society that owns it is so that human life is rich in culture and historical values. In addition, tradition will also make life harmonious.

There are several functions of tradition, namely

1. Historical Heritage Fragment Provider; the function of tradition is to provide the fragments of historical heritage that we find useful.

2. Providing a Legitimacy of a View of Life, The function of tradition is to provide legitimacy to existing views of life, beliefs, institutions and rules. 


\section{Provides a Symbol of Collective Identity}

4. The function of tradition is to provide a convincing symbol of collective identity, strengthen primodial loyalty to nations, communities and groups. Such as national traditions with songs, flags, emblems, mythology and general rituals.

5. As a place of escape, the function of tradition is to help as a place of escape from the complaints, discontent and disappointments of modern life

The commemoration of the birthday of the Prophet Muhammad SAW is not only a form of the implementation of the values of Islamic law, but in the procession of its implementation it is indisputable that cultural values are very thick in its implementation. This can be clearly seen from the sequence of activities and the ceremonial instruments used in general containing cultural messages from the community itself as adherents of Islamic teachings.

In a series of commemoration ceremonies for the birthday of the Prophet Muhammad SAW, it is usually filled with various social activities such as festivals, preferably for members of the poor. Usually they are placed in a certain place which is served with special dishes and the feast is recommended to be brought home to be eaten by other family members.

The commemoration of the Prophet Muhammad SAW's birthday begins with an agreement on the schedule, type of activity, the number of guests invited and the amount of funds needed. In the procession of the maulid commemoration activities, everything that will be carried out is usually mutually agreed upon and carried out jointly with the mutual cooperation system.Adat is a cultural idea consisting of cultural values, norms, customs, institutions, and customary laws that are commonly practiced in an area. If this custom is not implemented, there will be confusion which results in unwritten sanctions by the local community against the perpetrators who are considered deviant.

Ethnography is the study of the life and culture of a community or ethnic group, for example, customs, habits, law, art, religion, language. The area of study that is very close to ethnography is ethnology, which is a comparative study of the culture of various societies or groups (Richards et al., 1985) [3]. The term ethnography is actually an anthropological term, ethnography is the embryo of anthropology, born in the first stages of its development before the 1800s. Ethnogarafi is also the result of records of European explorers when looking for spices in Indonesia.

Koentjaraningrat argued "They recorded all interesting phenomena encountered during their travels, including, among other things, about the customs, community structure, language and physical characteristics of these ethnic groups" [4]. Ethnography, which has anthropological roots, is basically a researcher's activity to understand how people interact and work together through observable phenomena of everyday life. Ethnogarafi is a systematic depiction and analysis of a culture of a group, society or ethnic group gathered from the field in the same period of time. Before the term ethnography of communication became increasingly popular, the term ethnography of speaking was referred to earlier as giving the use of spoken language. Ethnography of communication is broader because it does not only cover the mode of spoken communication (speaking), but also involves written communication as well as communication with gestures, kinesics, or signing. Use of speech What are you ?, Comment alle vous? (in French), Hoe don't you het? (Dutch) with the same meaning, of course, different modes of appearance with utterances. Sincerely, Dear Sir, Beste Meneer, Sincerely yours, sincerely yours.

Ethnography has its roots in the fields of anthropology and sociology. Practitioners today carry out ethnographic research in organizations and societies in all forms. Ethnographers conduct studies of schooling, public health, rural and urban development, consumer and consumer goods, and any human arena.

According to Soekanto (2012: 154), seven elements of culture are considered as cultural universal, namely [5];

a. Equipment and supplies for human life (housing clothing, household weapons, means of production, transportation and the like;

b. Livelihoods and economic systems (livestock farming, production systems, retribution systems, etc.);

c. Social system (family system, political organization, legal system, marriage system;

d. Language (spoken or written)

e. Arts (fine art, sound art, movement art and so on

f. Knowledge system

g. Religion (belief system)

Culture has a very large function for humans and society. The various forces that society and its members have to face, such as natural forces, as well as other forces within society itself are not always good for him. In addition, humans and society also need satisfaction, both in the spiritual and material fields. For the most part, the needs of the people mentioned above are fulfilled by 
the culture which originates from the community itself. So the habit refers to a symptom that a person in his actions always wants to do regular things for him.

\section{RESEARCH METHODS}

The approach used in this research is a qualitative descriptive approach. In this study, a condition that aims to create a systematic, factual and accurate description of the facts, characteristics and relationships between the phenomena under study will be reported. The types and sources of data collected are primary data. The data obtained were then analyzed according to the data obtained.

This research was conducted in Kemukiamn Bambi, Peukan Baro District, Pidie Regency. The reason this place was used as a research location is because the area is almost $100 \%$ populated by Islam and the ceremony to commemorate the Prophet Muhammad SAW's birthday lasts for 100 days, starting from 12 months of Rabiul Awal to the end of Jumadil Awal and in fact several days in the month of Late Jumadil. .

The data needed in this study include secondary data and primary data. Secondary data were obtained from supporting literatures and data from related agencies if needed. Meanwhile, primary data were obtained from interviews and field observations. Field data collection was carried out through observation and interviews.

The data analysis technique in this study is to analyze the data obtained based on research data collection techniques. The data of the analysis were taken from the perspective of the maulid tradition from a sociological perspective.

\section{RESULTS AND DISCUSSION}

\subsection{Mawlid Implementation Tradition}

Hadi (2006: 19) quoted by Abidin Nurdin (2016: 46) mentions three patterns of the spread of Islam in the archipelago, namely; integrative, dialogic, and dialogic-integrative combination [6]. From the three stages, it can be seen, first, integrative, most aspects of life and culture of a community are integrated with the world view, world picture, knowledge system and Islamic values. For example, ethnic Malay communities in Aceh, Sumatra, Kalimantan, Palembang, Riau, Banjar, coastal Java such as Banten, East Java and Madura. This pattern can be done because before the king or ruler embraced Islam, the public had embraced Islam and developed an Islamic-style culture.

Second, dialogical; Islam is forced to have a dialogue with local traditions that are embedded in society. An example is in interior Java, which is directly under the influence of the kraton. Islamic mysticism developed in this area combined with the old mystical traditions inherited from the Hindu era. The art and literature of the Hindu era are preserved with an Islamic style. This pattern is carried out because the power system still maintains the old system, and society is still not fully Islamicized.

Third, the combined pattern of dialogue and integration occurs in Eastern Indonesia, for example in Sulawesi. This is because those who initially embraced Islam were kings and aristocrats, only then were followed by people with diverse cultures.

From these three explanations, the spread of Islam in the archipelago was carried out by approaching the culture and customs of the local community. Cultural and traditional approaches integrated into Islamic cultural values, which are then carried out routinely in the form of culture as part of a combination of local cultural values and Islam. Local cultural values are integrated with Islamic values into a tradition in the life of people in Indonesia. One of the traditions inherent and commemorated every day by the people of Indonesia in general and Aceh in particular is the Maulid Tradition. The Mawlid tradition is a combination of local culture and Islam, each year is commemorated as the birthday of the Prophet Muhammad SAW. The Mawlid tradition carried out by the people of Aceh is different from other regions in Indonesia,

The Mawlid tradition is a tradition and culture that developed in Acehnese society and is commemorated every year on the birthday of the Prophet Muhammad SAW with various activities arranged starting in the form of salawat rasul (Meudikee), meals together prepared in the homes of respective residents then brought to Meunasah in the form of dish, in that dish contains various kinds of food. From bue kulah (rice wrapped in banana leaves), Meulapek dishes (various kinds of dishes) and then at night a lecture on the history of the birth of the Prophet Muhammad SAW was held. The implementation of Mawlid has been carried out since Islam developed in Aceh and has been commemorated on the birthday of the Prophet Muhammad SAW, then it has been maintained until now.

The people of Aceh and the people of Bambi in particular continue to maintain the customs and traditions of Mawlid, it is considered that carrying out Mawlid brings blessings and a form of love to the Prophet. The implementation of Maulid in Aceh differs from one region to another, namely Maulid on the west coast of Aceh is different from the Maulid commemoration activity in the northern coast of Aceh. The difference in the implementation of the Maulid is more in the preparation and form of the 
dishes that are made. Even though the Bue Kulah (Banana Leaf Rice) looks the same, the content of the dish is different, which is called the meulapeh dish varies from region to region. Then the way to take a picnic (Meudikee) is also different, the differences can be seen in various kinds, from the lyrics, the movements, the number of people, different between regions. However, the overall nuances of the activities remain Islamic-oriented.

The commemoration of Maulid in Aceh is different from other regions, for example from the time, namely for three months, namely the month of Rabiul Awal, Rabiul Akhi and the month of Jumadil Awal (100 days). As explained above, there are differences in the celebration of Maulida in several regions in Aceh, influenced by cultural, social and traditional aspects in the community, but the implementation of Maulid still has Islamic nuances. Especially for the implementation of Maulid in the Bambi settlement every year and all villages (gampong) participate in the implementation sequentially, not simultaneously when one village is with another gampong. Every year, almost all the people of Kemukiman Bambi eagerly celebrate Pang Ulei (Rasulullah). Mukim and gampong apparatus before carrying out Mawlid held a meeting with residents either in Meunasah or the Bambi Mosque and the meeting participants consisted of the Geuchik of each village and their apparatuses, community leaders, religious scholars / Dayah leaders (Pasantren). In the meeting discussed the determination of the Mawlid schedule as agreed upon by each village. If each village has been scheduled, the Geuchik will hold a meeting in each village with the community to discuss in detail the activities of the maulid commemoration ceremony in the village.

\subsection{Encouraging and Inhibiting Factors for the Implementation of Mawlid}

\section{a. Driving Factor}

(Hoesein, 1970: 1) quoted in Abidin Nurdin (2016: 49) The philosophy of life of the Acehnese people is the integration between the hukom ngon adat (religion and adat) contained in the hadih majah (proverb) "Hukom ngon Adat lagee substances ngon sipheut" (law religion] and customs as substances and characteristics, cannot be separated) [7]. There are other students; "Hukom meunyo hana adat tabeue, adat meunyo hana hukom bateue" (law if without adat is tasteless, adat if without law is invalidated) (Muhammad \& Sumardi, 2011: 37) [8]. It can be understood that culture and Islamic teachings have interacted and assimilated harmoniously in the Acehnese society for hundreds of years. The concrete forms of customs and culture in the life of the people of Aceh are not only applied in the social, economic and political fields, but also in the legal field (Nurdin, 2013: 139) [9].

The factor that encourages the people of Aceh in general and the Bambi settlement especially in the implementation of Maulid is a deep belief in the community, that by carrying out the feast of maulid, is a form of expressing their love for the Prophet, with an understanding of getting intercession, reward, adding sustenance and bringing blessings to his family . For this belief, they are willing to insert the sustenance they get every day to save or save for the activities of the maulid feast. Some of them also prepare the maulid feast by choosing livestock. They prepare livestock, namely chickens, ducks, goats and others from the start, so they can slaughter them during the maulid feast. There are also rice farmers, When they harvest, they still save their rice for the intersection in preparation for them to carry out the maulid feast. That was the enthusiasm of the people of Aceh and Kemukiman Bambi in carrying out the Maulid feast. The belief and belief that those who carry out the Maulid feast bring blessings of sustenance, and as a form of their love for the Prophet.

From the explanation above, it can be seen that the enthusiasm of the people of Kemukiman Bambi to carry out the maulid feast, all social strata mingle and gather at Meunasah, work together to clean up the Meunasah yard to make a stage / mibar for Maulid lectures. The mothers at home prepare meals and meals, all the food that has been prepared is included in a dish called 'meulapeh dish', 'bue kulah'. Meulapeh dishes are made in sizes that can contain all the food prepared, namely fish, vegetables, meat, crackers, bananas, fruits, traditional cakes, and added with Bue Kulah (rice wrapped in banana leaves), after that, just take it to Meunasah to eat together, and also to all those present. So all the food that had been prepared and brought to Meunasah was gone. In Meunasah, besides eating together, "Meudikee Maulid" or taking care of the prophet was also made. Meudukee Maulid about praising the Messenger of Allah until after eating, then continue at night to listen to Islamic lectures. So angry was the implementation of the Prophet's birthday in Aceh and in the Bambi settlement, all were involved, and this was also part of the form of unity and integrity of the ummah, helping each other, sharing sustenance and friendship. This is the driving force for the people of Bambi to carry out Mawlid, they believe that with the feast of maulid brings blessings, intercession, sharing of sustenance and no less important is building friendship between residents and community unity. then continued at night to listen to the discourse of Islam. So angry was the implementation of the Prophet's birthday in Aceh and in the Bambi settlement, all were involved, and this was also part of the unity and integrity of the ummah, helping each other, sharing sustenance and friendship. This is the driving force for the people of Bambi to carry out Mawlid, they believe that with the feast of maulid brings blessings, intercession, sharing of sustenance and no less important is building friendship between residents and community unity. then continued at night to listen to the discourse of Islam. So angry was the implementation of the Prophet's birthday in Aceh and in the Bambi settlement, all were involved, and this was also part of the unity and integrity of the ummah, helping each other, sharing sustenance and friendship. This is the driving force for the people of Bambi to carry out Mawlid, they believe that with the feast of 
maulid brings blessings, intercession, sharing of sustenance and no less important is building friendship between residents and community unity.

Various dishes are also provided such as Meulapeh dishes. Meulapeh dish is the arrangement of the contents of the dish arranged in such a way in layers (meulapeh) the order of arranging plates containing food (menu) specifically for the maulid feast. Usually the menu arrangement for the maulid feast is certain, namely there is a main menu and there is a complementary menu. The main menu consists of; nasi (bu) kulah (wrapped in a cone with smoked banana leaves); The side dishes consist of white and red cooked duck, red cooked chicken, stir-fried and fried milkfish, roasted rambeue fish, salted duck egg, sauteed shrimp, cooked rendang / meat curry, while the complementary menu consists of; Long bean vegetable tojo, gado-gado, fried chili sauce, fruits (usually grapefruit, sapodilla, jackfruit, papaya).

The dishes that are displayed are usually the appearance of the dishes and the menu arrangement is generally the same, we cannot distinguish dishes from members of the poor community from dishes from figures / officials or rich people. The implementation of each village is in accordance with the agreed time schedule at the joint meeting at the Bambi settlement level. In addition to the feast with the meulapeh, it is also coupled with the activities of donating orphans, zikir Berzanji activities and Islamic lectures on the history of the birth of the Prophet Muhammad SAW.

Maulid is an event that is always awaited every year. The benefits as explained by Tgk. Imum Kemukiman Bambi is a form of preservation of culture and customs, which have been entrenched in the Bambi community as syiar Islamic Sharia. From the social aspect, there is a sense of togetherness among the people, rich, poor, leaders, scholars, youth, women and all levels of society. For religious aspects, the commemoration of the birthday of the Prophet Muhammad is worship, a series of religious lectures that tell about the history of the Apostolate of Muhammad SAW. In the aspect of tradition, collective agreement does not highlight differences among members of the community, develops mutual knowledge and feelings of one another even though they are different from their social status.

\section{b. Obstacle factor}

Some of the factors inhibiting the implementation of Mawlid are;

1) From an economic perspective

Economy is one of the developments that needs attention, because it involves 3 things, namely production, distribution and consumption. Understanding economics in general is one of the social sciences that studies human activities related to the production, distribution and consumption of goods and services. Economics is widely studied and is often associated with household finances. According to Samuel dEconomic efficiency is a method used by a person or a group of people in utilizing limited resources to obtain various kinds of commodities and products and distribute them so that they can be consumed by the public at large.

Based on this study, it can be explained that the economy has an important role in life. In the Bambi settlement, some of the people in the community have a very weak economy and income. Generally, their livelihood is as farmers. Apart from agriculture, a small proportion of people work in home industries, and some are civil servants. The economic factor, one of the obstacles for the people of Kemukiman Bambi, is not being able to participate in the maulid celebration. The implementation of the Mawlid requires a large amount of funds for the preparation of the Bue Kulah and Idang Meulapeh festivals.

\section{2) Understanding / qilafiah opinion}

Maulid celebration is one of the most important things for some people. The understanding of maulid for most people is the birthday of the prophet as well as milad which means "birth" so it can be interpreted as commemorating the birthday of the Prophet Muhammad SAW. The goal is to commemorate the birthday of the great Muslim figure, the Prophet Muhammad SAW, by performing many prayers. So it is a birthday celebrated and with great fanfare.

In contrast to several other opinions, there are some opinions expressing that the celebration of the birthday is not necessary because it leads to redundancy. This understanding was refuted based on an event carried out with the opinion of the maulid meaning-eating event and was never celebrated when the Prophet Muhhammad was alive. A small number of community groups in the Bambi settlement do not agree with the maulid celebration. The differences are based on different understandings about the maulid and different schools of thought in Islam. However, this difference does not have an impact on religious conflict, so that it does not affect the general celebration of the maulid that is carried out by residents of the Bambi settlement.

\subsection{Symbol and meaning}

There are several symbols and meanings which can be described as follows; 
a) $\mathrm{Bu}$ kulah (rice wrapped in banana leaves) in the shape of an inverted cone or pyramid. Bu kulah is the main menu that must be present. Bu kulah is made as one of glory and majesty. Bu kulah is usually served or served to previous kings as well as for great guests who visit the palace.

b) The meulapeh (layered dish) idea is a series of small plates arranged in a tray containing a variety of dishes. The small plates arranged on the tray or in the basket with the number must be odd (according to the odd number of numbers that are favored by the Divine).

c) Ija peunetop (cloth covering) the cover cloth has several colors, each color has its own meaning. Yellow symbolizes greatness / greatness / goldenness (Kenduri Maulid is an activity of greatness / majesty), green is symbolized by coolness (feast maulid is a social activity of sincere sharing) while red indicates a firm and courageous nature (describing the nature and character of the fast Acehnese people. and open).

\section{REFERENCES}

1. Shadily, Hassan 1993, Sosiologi untuk Masyarakat Indonesia, Jakarta: PT Rineka Cipta.

2. Suyono, Ariyono. 1985. Kamus Antropologi. Jakarta: Akademika.

3. Richard, Aggiss. 1985. Coaching Hockey The Australian Way. Melbourne: Renwick Pride

4. Koentjaraningrat. 1989. Metode Penelitian Masyarakat. Jakarta: Gramedia. Pustaka.

5. Soekanto, Soerjono, 2012.Sosiologi Suatu Pengantar. Jakarta : Rajawali Pers.

6. Nurdin, Abidin. 2016. Integrasi Agama dan Budaya, Kajian Tentang Tradisi Maulud Dalam Masyarakat Aceh”.

7. Hoesein, Moehammad. 1970. Adat Atjeh. Banda Aceh: Dinas Kebudayaan Provinsi Daerah Istimewa Aceh.

8. Muhammad, Rusjdi Ali \& Sumardi, Dedy. 2011. Kearifan Tradisional Lokal: Penyerapan Syariat Islam dalam Hukum Adat Aceh. Banda Aceh: Dinas Syariat Islam.

9. Nurdin, Abidin. 2013. Revitalisasi Kearifan Lokal Aceh: Peran Budaya dalam Menyelesaikan Konflik Masyarakat. Jurnal Analisis. Volume XIII, Nomor 1, Juni. 